\title{
A New Motivation for Sustainable Trade Between Countries with Different Regulatory Qualities
}

\author{
Wenshou Yan ${ }^{1, *}$ and Xi Yang ${ }^{2}$ \\ 1 School of Business Administration, Zhongnan University of Economics and Law, Wuhan 430073, China \\ 2 School of Management, Hubei University of Chinese Medicine, Wuhan 430065, China; \\ glxy2004@hbtcm.edu.cn \\ * Correspondence: wenshou.yan@zuel.edu.cn
}

Received: 3 December 2019; Accepted: 24 December 2019; Published: 25 December 2019

\begin{abstract}
In the context of rising anti-globalization sentiments, countries tend to trade with superior government institutions for a longer period and with a higher volume of exports. This phenomenon hinders sustainable trade between countries with different regulatory qualities, resulting in negative effects for developing countries that have poor institutional quality. Using a large panel dataset covering 192 countries during the period 1996-2017, this paper investigates the effect of relatively better government quality on exports. This quality is measured by said government's regulatory quality relative to its trade partner. The empirical results indicate that a country with relatively better institutional quality receives at least $4 \%$ higher exports (dubbed as a premium gain), keeping other factors constant. The empirical result remains the same when solving the endogeneity issue and when applying alternative estimation methods. This paper thus proposes a new channel for sustainable trade for countries characterized by different institutional qualities.
\end{abstract}

Keywords: sustainable trade; institutional quality; premium effect; gravity model; zero trade

\section{Introduction}

In the context of rising anti-globalization sentiments, countries tend to serve those destination countries with better government institutions for a longer period [1]. This phenomenon hinders sustainable trade between countries with different regulatory qualities, resulting in negative effects for developing countries that have poor institutional quality. According to previous literature, democratic countries are more likely to trade with one another [2], mainly because domestic political institutions are important determinants when choosing a trading partner. Obviously, developed countries (i.e., the Global North) have better institutions than developing ones (i.e., the Global South) [3,4]. This leads to a lower possibility of trade between the Global North and Global South. This paper provides a new channel for countries with better regulatory quality to sustainably trade with countries with relatively poor regulatory quality.

Institutional quality is considered a driver of economic development $[5,6]$. It helps establish incentive structures that bring efficiency, reduce uncertainty, and contribute to healthier economic performance [7]. As a fundamental driver of economic growth, trade is profoundly affected by government institutions [8-11] - a theory that is unanimously accepted by politicians, economists, and policymakers in both democratic and autocratic countries.

This paper provides a new potential channel for countries with relatively better institutional quality to gain from their exports when trading with countries with relatively poor institutional quality. We examine how having better institutional quality relative to a trading partner affects exports. Figure 1 presents descriptive and institutive evidence to support the theory that relatively better institutional quality affects exports. It plots the absolute difference of institutional quality between the exporter and 
its partner on the horizontal axis, while the logarithmic value of the exports is shown on the vertical axis. A government who has a higher institutional quality than its trade partner sees the value of its exports increase.

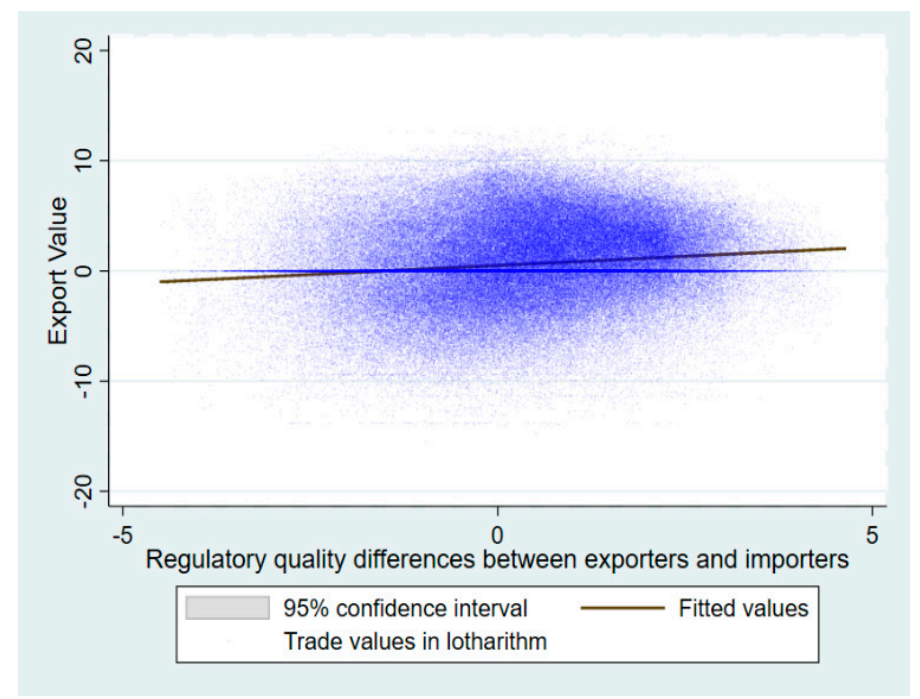

Figure 1. Export premiums of a government with better institutional quality than its trading partner.

In this paper, using a large panel dataset consisting of 192 countries for the period 1996-2017, as well as the standard gravity model, we investigate the effect of relatively better government institutional quality, as measured by regulatory quality relative to its trade partner, on exports. The empirical results show that a country with relatively better institutional quality receives at least $4 \%$ higher exports, which is a premium gain when trading with a country with relatively poor institutional quality. The results show that when other factors are kept constant, when the endogeneity issue is solved, and when alternative estimation methods are applied, the effect of this relationship is statistically and economically significant and robust.

This research provides another mechanism through which better institutions can contribute to economic growth and help international traders choose their partners. We argue that these potential channels include both exporters and importers. For exporters, having a relatively better government as a comparative advantage means they can export in an efficient way. Exporters also choose to trade with countries with better institutions. We conclude that these new findings provide strong incentives for the relatively better institutional quality of the Global North to trade with the lower institutional quality of the Global South.

With this aim in mind, this paper unfolds as follows. Section 2 reviews the related literature. Section 3 presents the identification method as well as the data used in the empirical analysis and the data sources. Section 4 presents the empirical results. The robustness checks, including other alternative estimation results, zero trade, and trade self-selection issues, are analyzed in Section 5. The final section, Section 6, concludes the paper by presenting critical policy implications as well as potential areas for future research.

\section{Brief Literature Review}

A vast body of literature on international trade proposes that government institutions affect both the choice of trading partners and trading volume [1,12-15]. Nunn and Trefler [9] conclude that domestic institutions can have a significant effect on international trade and argue that while the comparative advantages of institutions are different from the comparative advantages of traditional sources, they are quantitatively related to each other. Ju and Wei [16] further argue that this point is particularly relevant for economies with low-quality institutions, where institutional factors can be 
more important than factor endowment in determining their comparative advantage. If institutions are of better quality, there will be a higher possibility of contracts being enforced. Ferguson and Formai [17] also state that "Institutional quality contributes to a country's comparative advantage in the same way as the more traditional sources such as factor endowments and technology." De Groot et al. [18] found that institutional quality and the quality of governance have a significant, positive, and substantial impact on bilateral trade. Democratic institutions have also been shown to have positive effects on trade. For example, by applying an augmented gravity model, Yu [15] found that democratization significantly increases trade, potentially contributing between $3 \%$ and $4 \%$ to bilateral trade growth.

For different dimensions of institutional quality, Pierre and Sekkat [19] observed that exports of manufactured goods are positively affected by the quality of institutions but not by total exports or non-manufactured exports. In relation to the two types of trade margins, political institutions matter more for the extensive than the intensive margin due to the application of highly disaggregated product-level trade data [20]. There are several channels through which democracy may affect trade, with differing implications and specific institutional dimensions also found to affect it. First, democratization in the exporting country can improve product quality and reduce trade costs, thus increasing bilateral trade. Second, democratization in the importing country may increase trade barriers and thus reduce imports. A study by Anderson and Young [21] that investigated the associations between the quality of institutions and trade confirmed that the lack of enforcement of contracts may act as a tariff on risk-neutral traders, therefore reducing trade.

Thus, governments should ascribe high priority to further improving the legal environment and better enforcing property rights and contracts [22]. Levchenko [13] also proposes a simple international trade model that incorporates institutional differences within the framework of incomplete contracts. Beverelli et al. [23] identified the critical role institutions play for importing countries in terms of shaping the trade-promoting effect. This indicates that countries with high institutional quality benefit the most from lower service-trade restrictions in terms of increased productivity in downstream industries.

All in all, institutional quality drives trade flows [18], while weak or inadequate institutions can greatly restrain trade in the same way that the introduction of tariffs can [24,25]. Weak domestic institutions tend to hinder trade flows, as they exert higher transaction costs on economic agents [26] and adversely affect the comparative advantage of countries with low-quality institutions [27].

The literature documents the effects of absolute institutional quality on economics and trade. Moving beyond previous research, this paper focuses on the effect of relative institutional quality on the country's exports. As discussed in the introduction, in the context of anti-globalization, where countries tend to trade with countries with better institutions, this paper provides a potential new framework for sustainable trade between countries with different institutional qualities.

\section{Identification Strategy and Data Sources}

\subsection{Identification Strategy}

We are interested in determining whether a country with relatively better institutional quality receives a premium gain in international trade. The gravity model of trade is applied, with the variables being government institutional quality. The embedded relative of better institutional quality, BGI $_{i j t}$, is the main variable, which is equal to one if the exporter's institutional quality is better than that of its trade partner, and zero otherwise.

$$
\log \left(\text { Export }_{i j t}\right)=a+\gamma B G I_{i j t}+\beta^{\prime} Z_{i j t}+\delta_{i}+\delta_{j}+\delta_{t}+\varepsilon_{i j t} .
$$

The dependent variable is the unidirectional trade values, rather than the average total trade volume, from country $i$ to country $j$ at time $t$. According to Baldwin and Taglioni [28], averaging the reciprocal trade flows will lead to a "silver medal" mistake estimation derived from a theoretically founded gravity equation. 
The vector $Z_{i j t}$ captures the conventional control variables, such as the gross domestic product (GDP), geographic distance between two trade partners, landlocked county dummy, island country dummy, common language, colonial relationship effect, and the absolute values of institutional quality, measured by regulatory quality. Regulatory quality focuses on the quality of implemented policies and includes the perceived incidence of policies that inhibit the market mechanism as well as the excessive regulation of foreign trade and business development. As such, it closely reflects the transaction costs that result from the state's policy intrusion into private trade. Broadly, government institutional quality is measured using the following six indicators: democratic accountability, government effectiveness, political stability and absence of violence/terrorism, regulatory quality, control of corruption, and the rule of law. In this paper, we focus on the effects of regulatory quality on exports. The export and import country fixed effects are denoted by $\delta_{i}$ and $\delta_{j}$, and the time fixed effect is denoted by $\delta_{t}$. Anderson and van Wincoop [29] present the theory that the gravity model should include the multilateral "resistance term." Moreover, Feenstra [30] points out that estimation issues can be solved using country fixed effects. The last term, $\varepsilon_{i j t}$, represents the myriad of other influences on exports, which are assumed to be well-behaved.

Readers may be concerned with the time series properties of relatively better government institutional quality. First, in this paper, we construct the variable of interest as a dummy variable, which, theoretically, does not raise the important issue of whether the variable is stationary or not. Second, regarding the definition of long panel data, we use data covering a period of 21 years $(T)$ and 192 countries $(N)$, which is larger $N$ and smaller $T$ panel data. With these time series properties, we therefore proceed under the assumption that there is no serious unit root for the period 1996-2017.

\subsection{Addressing Potential Endogeneity}

The hypothesis of the two-way fixed-effect model, as discussed above, is that the relatively better institutional indicator is an exogenous variable if the conditional independence assumption (CIA) is satisfied [31]. The CIA indicates that the partial effect of relatively better institutional quality is identified by controlling for all of the observed characteristics. The CIA is equivalent to the random assigned experiment (see Angrist and Pischke [31], pp. 51-59). However, the dummy variable could be related to other variables that vary across time and countries. If some control variables vary in this way, the estimation bias cannot be solved by applying the two-way fixed-effect method. The varying uncontrolled variables could affect the relatively better government indicator and the outcome variable resulting from sample selection bias. To address this potential endogeneity issue, Heckman's [32] sample selection model can be used to compensate for sample selection bias. Thus, we apply the treatment effect model to identify the effects of relatively better institutional quality on its exports. This is displayed below. The selection equation (first stage) is

$$
B G I_{i j t}^{*}=X_{i j t} \gamma+\mu_{i j t}
$$

and the regression equation (second stage) is

$$
\log \left(\text { Export }_{i j t}\right)=\rho^{\prime} Z_{i j t}+\varphi B G I_{i j t}+\omega_{i j t}
$$

where $\mu_{i j t}$ and $\omega_{i j t}$ are bivariate normal distributions with a mean of zero and a covariance matrix, respectively. Given incidental truncation as well as the fact that $B G I_{i j t}$ is an endogenous dummy variable, the estimation looks to use the observable variables to estimate $\varphi$ when controlling for other variables, thus solving the selection bias.

In the first stage, $B G I_{i j t}^{*}$ is estimated using the probit model, as shown in Equation (2). The effect of relative better government is estimated after controlling for the inverse of Mill's ratio, which reflects the degree of selection bias, as shown in Equation (3). If a country's institutional quality is better than that of the average (or median) of other countries, the country has a higher probability of having relatively better institutional quality than that of its trade partner. The logic is that if the country has 
relatively better government institutional quality than the average (or median) of all the countries, the country has more of an ability to be better than that of its trade partner. We use this new indicator as an exogenous variable to indicate relatively better institutional quality in the first stage. The merit of the treatment effect model is to solve the non-pure randomized assignment of the variable of interest. In addition, the year fixed effect and country fixed effect are controlled and the clustered standard errors applied to deal with heteroscedasticity variance.

\subsection{Data Sources}

The trade dataset is taken from Glick and Rose [33] and Rose [34]. This dataset covers bilateral trade for over 200 International Monetary Fund countries between 1948 and 2017, as well as other variable data that indicate country characteristics such as GDP per capita, population, geographic distance between two trade partners, island country dummy, landlocked country dummy, colonial relationship effect, common language dummy, currency union dummy, regional trade agreement, and trade prices. The government institutional quality (regulatory quality) dataset covering the period 1996-2017 is drawn from the Worldwide Governance Indicators [35]. We merged the two datasets, and the countries covered in this study are listed in Table A1 of the Appendix A. The variable of interest is relatively better institutional quality, which is calculated based on institutional quality indicators. The summary statistics of these variables are shown below in Table 1.

Table 1. Summary statistics.

\begin{tabular}{|c|c|c|c|c|c|c|}
\hline Variables & Variables & Obs. & Mean & Std. Dev. & Min. & Max. \\
\hline $\ln$ (Exports) & Log of exports & 397,346 & 0.54 & 3.09 & -18.65 & 12.98 \\
\hline Relative & $\begin{array}{l}\text { Relatively better institutional } \\
\text { quality }\end{array}$ & 396,241 & 0.64 & 0.48 & 0.00 & 1.00 \\
\hline ReqEX & $\begin{array}{l}\text { Regulatory quality for } \\
\text { exporters }\end{array}$ & 341,207 & 0.13 & 1.00 & -2.65 & 2.26 \\
\hline ReqIM & $\begin{array}{l}\text { Regulatory quality for } \\
\text { importers }\end{array}$ & 390,549 & -0.19 & 0.91 & -2.65 & 2.26 \\
\hline $\ln ($ GDPEX) & Log of GDP for exporters & 297,261 & 11.42 & 2.22 & 4.58 & 16.69 \\
\hline $\ln ($ GDPIM $)$ & Log of GDP for importers & 309,055 & 11.01 & 1.92 & 5.60 & 16.69 \\
\hline $\ln (\mathrm{GDPpcEX})$ & $\begin{array}{l}\text { Log of GDP per capita for } \\
\text { exporters }\end{array}$ & 367,020 & 8.84 & 1.40 & 5.18 & 11.82 \\
\hline $\ln (\mathrm{GDPpcIM})$ & $\begin{array}{l}\text { Log of GDP per capita for } \\
\text { importers }\end{array}$ & 379,547 & 8.41 & 1.33 & 5.18 & 11.82 \\
\hline $\ln ($ POPEX) & Log of population for exporters & 375,570 & 15.61 & 2.16 & 9.13 & 21.05 \\
\hline $\ln ($ POPIM) & Log of population for importers & 384,672 & 15.48 & 2.02 & 9.13 & 21.02 \\
\hline $\ln$ (Distance) & Log of geographic distance & 390,063 & 8.30 & 0.76 & 3.68 & 9.422 \\
\hline Island & Island country dummy & 320,815 & 0.43 & 0.58 & 0.00 & 2.00 \\
\hline Landl & Landlocked country dummy & 320,815 & 0.41 & 0.57 & 0.00 & 2.00 \\
\hline Border & Land border dummy & 390,063 & 0.02 & 0.12 & 0.00 & 1.00 \\
\hline Colony & $\begin{array}{l}\text { Dummy for trade partners who } \\
\text { had previous colonial } \\
\text { relationship }\end{array}$ & 390,063 & 0.01 & 0.09 & 0.00 & 1.00 \\
\hline Comlang & Common language dummy & 390,063 & 0.17 & 0.38 & 0.00 & 1.00 \\
\hline Curruinon & Currency union dummy & 390,063 & 0.02 & 0.12 & 0.00 & 1.00 \\
\hline RTA & $\begin{array}{l}\text { Regional trade agreement } \\
\text { dummy }\end{array}$ & 390,063 & 0.09 & 0.29 & 0.00 & 1.00 \\
\hline TRpriceEX & Trade price level for exporters & 397,346 & 0.94 & 0.56 & 0.00 & 2.22 \\
\hline TRpriceIM & Trade price level for importers & 397,346 & 0.96 & 0.53 & 0.00 & 2.22 \\
\hline
\end{tabular}

Table 2 shows the correlations between the variable of interest and the core control variables. It also shows the correlations between the dependent variable and all of the important independent variables. The correlation results show that exports are positively related to the country's size, government institutions, and relatively better government institutional quality, but are negatively related to distance. The correlations will be empirically tested in Section 4 . 
Table 2. Correlation metrics.

\begin{tabular}{cccccccc}
\hline & $\ln$ (Exports) & Relative & ReqEX & ReqIM & $\ln$ (GDPEX) & $\ln$ (GDPIM) & $\ln$ (Distance) \\
\hline $\ln$ (Exports) & 1 & & & & & & \\
$p$-value & $\mathrm{n} / \mathrm{a}$ & & & & & & \\
Relative & 0.1047 & 1 & & & & & \\
$p$-value & $(0.0000)$ & $\mathrm{n} / \mathrm{a}$ & & & & & \\
ReqEX & 0.3215 & 0.5835 & 1 & & & & \\
$p$-value & $(0.0000)$ & $(0.0000)$ & $\mathrm{n} / \mathrm{a}$ & & & & \\
ReqIM & 0.1374 & -0.4590 & 0.0213 & 1 & & & \\
$p$-value & $(0.0000)$ & $(0.0000)$ & $(0.0000)$ & $\mathrm{n} / \mathrm{a}$ & & & \\
$\ln$ (GDPEX) & 0.4660 & 0.1606 & 0.3420 & 0.0339 & 1 & & \\
$p$-value & $(0.0000)$ & $(0.0000)$ & $(0.0000)$ & $(0.0000)$ & $\mathrm{n} / \mathrm{a}$ & & \\
$\ln$ (GDPIM) & 0.2705 & -0.1247 & -0.0001 & 0.2739 & 0.0206 & 1 & \\
$p$-value & $(0.0000)$ & $(0.0000)$ & $(0.9608)$ & $(0.0000)$ & $(0.0000)$ & $\mathrm{n} / \mathrm{a}$ & \\
$\ln$ (Distance) & -0.2237 & 0.0384 & 0.0080 & -0.0658 & -0.0287 & -0.0011 & 1 \\
$p$-value & $(0.0000)$ & $(0.0000)$ & $(0.0000)$ & $(0.0000)$ & $(0.0000)$ & 0.5315 & $\mathrm{n} / \mathrm{a}$ \\
\hline
\end{tabular}

\section{Empirical Results}

\subsection{Benchmark Results}

Table 3 reports the ordinary least square (OLS) results using the logarithm of exports as the dependent variable. The variable of interest is relatively better institutional quality. Column (1) shows that relatively better government institutional quality has a positive effect on exports when the absolute values of government institutional qualities are controlled for both exporters and importers. The robust standard error is applied in Column (2) to deal with the potential heteroscedasticity issue, and the significance does not change. GDP for the exporters and importers is added as a control variable in Column (3). Other control variables included in the traditional gravity model, such as geographic distance, landlocked country dummy, island country dummy, common language, previous colonial relationship, and currency union, are added in Columns (4) and (5) as additional control variables. Keeping other factors constant, the governments with relatively better institutional quality have $45 \%$ higher exports than governments with relatively poor institutional quality. The formula to compute this effect is $\left(e^{\beta_{i}}-1\right) \times 100 \%$, where $\beta_{i}$ is the estimated coefficient. We apply this coefficient in Column (6) to calculate the effect size.

The reader may be concerned about the R-square values. In Column (1), the three variables explain roughly $13 \%$ of the variation of exports. However, when we add more control variables, the model in Column (6) explains about 50\% of the variation of exports, thus confirming that our model has strong explanatory ability. Furthermore, in our paper, we focus more on the effects of relatively better government institutional quality on exports rather than the fitting criteria of the full model. Finally, in social science, it is difficult to obtain a higher R-square due to the complexity of the economic system and because having too many factors, such as productivity, factor endowments, increasing return of the economy, market structure, and demand structure, would affect exports. These factors are not included in our estimation. 
Table 3. Reduced form regressions with more control variables.

\begin{tabular}{|c|c|c|c|c|c|}
\hline & (1) & (2) & (3) & (4) & (6) \\
\hline Variables & $\begin{array}{c}\text { OLS } \\
\ln \text { (Exports) }\end{array}$ & $\begin{array}{c}\text { OLS } \\
\ln \text { (Exports) }\end{array}$ & $\begin{array}{c}\text { OLS } \\
\ln \text { (Exports) }\end{array}$ & $\begin{array}{c}\text { OLS } \\
\ln \text { (Exports) }\end{array}$ & $\begin{array}{c}\text { OLS } \\
\ln \text { (Exports) }\end{array}$ \\
\hline Relative & $\begin{array}{c}0.238^{* * *} \\
(0.017)\end{array}$ & $\begin{array}{c}0.238^{* * *} \\
(0.017)\end{array}$ & $\begin{array}{c}0.303^{* * *} \\
(0.019)\end{array}$ & $\begin{array}{c}0.394^{* * *} \\
(0.019)\end{array}$ & $\begin{array}{c}0.372 * * * \\
(0.019)\end{array}$ \\
\hline ReqEX & $\begin{array}{c}0.939 * * * \\
(0.007)\end{array}$ & $\begin{array}{c}0.939 * * * \\
(0.007)\end{array}$ & $\begin{array}{c}0.600^{* * *} \\
(0.008)\end{array}$ & $\begin{array}{c}0.573 * * * \\
(0.008)\end{array}$ & $\begin{array}{c}0.531^{* * *} \\
(0.008)\end{array}$ \\
\hline ReqIM & $\begin{array}{c}0.564 * * * \\
(0.007)\end{array}$ & $\begin{array}{c}0.564 * * * \\
(0.008)\end{array}$ & $\begin{array}{c}0.427 * * * \\
(0.008)\end{array}$ & $\begin{array}{c}0.357^{* * *} \\
(0.009)\end{array}$ & $\begin{array}{c}0.308^{* * *} \\
(0.009)\end{array}$ \\
\hline $\ln ($ GDPEX) & & & $\begin{array}{c}0.676^{* * *} \\
(0.003)\end{array}$ & $\begin{array}{c}0.633^{* * *} \\
(0.003)\end{array}$ & $\begin{array}{c}0.636^{* * *} \\
(0.003)\end{array}$ \\
\hline $\ln ($ GDPIM $)$ & & & $\begin{array}{c}0.512 * * * \\
(0.003)\end{array}$ & $\begin{array}{c}0.520 * * * \\
(0.003)\end{array}$ & $\begin{array}{c}0.521^{* * *} \\
(0.003)\end{array}$ \\
\hline $\ln$ (Distance) & & & & $\begin{array}{c}-0.821 * * * \\
(0.008)\end{array}$ & $\begin{array}{c}-0.645^{* * *} \\
(0.009)\end{array}$ \\
\hline Island & & & & $\begin{array}{c}0.082^{* * *} \\
(0.013)\end{array}$ & $\begin{array}{c}0.042^{* * *} \\
(0.013)\end{array}$ \\
\hline Landl & & & & $\begin{array}{c}-0.247^{* * *} \\
(0.010)\end{array}$ & $\begin{array}{c}-0.210 * * * \\
(0.010)\end{array}$ \\
\hline Border & & & & $\begin{array}{c}1.675^{* * *} \\
(0.047)\end{array}$ & $\begin{array}{c}1.330 * * * \\
(0.047)\end{array}$ \\
\hline Colony & & & & & $\begin{array}{c}1.514^{* * *} \\
(0.034)\end{array}$ \\
\hline Comlang & & & & & $\begin{array}{c}0.452 * * * \\
(0.015)\end{array}$ \\
\hline Curruinon & & & & & $\begin{array}{c}0.603^{* * *} \\
(0.042)\end{array}$ \\
\hline RTA & & & & & $\begin{array}{c}0.804^{* * *} \\
(0.020)\end{array}$ \\
\hline Constant & $\begin{array}{c}0.457^{* * *} \\
(0.010)\end{array}$ & $\begin{array}{c}0.457 * * * \\
(0.010)\end{array}$ & $\begin{array}{c}-12.692 * * * \\
(0.047)\end{array}$ & $\begin{array}{c}-5.518^{* * *} \\
(0.081)\end{array}$ & $\begin{array}{c}-7.177^{* * *} \\
(0.086)\end{array}$ \\
\hline Observations & 335,445 & 335,445 & 224,671 & 184,631 & 184,631 \\
\hline R-squared & 0.126 & 0.126 & 0.416 & 0.479 & 0.490 \\
\hline
\end{tabular}

Notes: Robustness standard errors are reported in parentheses; ${ }^{* * *} p<0.01$; all of the regressions are clustered at country pair level; country and year dummies are not reported here.

\subsection{Fixed-Effect Model Estimation}

Even though the baseline regressions have controlled all of the variables that should be included in a traditional augmented gravity model, the effect of relatively better institutional quality on exports could be potentially confounded by some unobservable factors that are fixed with time or within countries. In addition, an important factor regarding the choice of estimation method concerns the gravity theoretical model [29]. The trade volume is not only affected by the trade cost of the trade partners but also by the third country's trade cost, which is referred to by Anderson and Wincoop [29] as multilateral trade assistance. The issue of multilateral trade assistance could be solved by controlling the importer and exporter dummy variables [36] or the country effect. Here, the country effect is not identical to "fixed effects," which refer to the dummy variables that make up each individual pair. Thus, Table 4 reports the estimation results, applying the two-way fixed-effect model to control for unobserved factors and to deal with the issue of multilateral trade assistance.

Column (1) shows the effects of relatively better institutional quality on exports when only the absolute value of institutional qualities from trade partners and the year fixed effect are controlled for. The estimation results show that relatively better institutional quality significantly contributes to the increase of exports. Column (2) adds the country fixed effects into the regression, based on Column (1). Column (3) applies the cluster standard errors at the national level to deal with the heteroscedasticity issue. Columns (4) and (5) add GDP for trade partners and regional trade agreements as the control variables, respectively. The estimation results are still shown to be statistically significant. However, the effect size decreases to around 0.1 when compared with the estimated effect size in Table 3, meaning 
that the variable of interest is highly correlated with the unobserved factors, and the fixed-effect model could partial out some of the confounded effects, meaning that the unobserved fixed year and country fixed effects are positively related to relatively better government institutional quality.

Table 4. Fixed-effect model estimation.

\begin{tabular}{|c|c|c|c|c|c|}
\hline & (1) & (2) & (3) & (4) & (5) \\
\hline Variables & $\begin{array}{c}\mathrm{FE} \\
\ln (\text { Exports) }\end{array}$ & $\begin{array}{c}\text { FE } \\
\ln (\text { Exports) }\end{array}$ & $\begin{array}{c}\text { FE } \\
\ln (\text { Exports) }\end{array}$ & $\begin{array}{c}\mathrm{FE} \\
\ln (\text { Exports) }\end{array}$ & $\begin{array}{c}\mathrm{FE} \\
\ln \text { (Exports) }\end{array}$ \\
\hline Relative & $\begin{array}{c}0.045^{* * *} \\
(0.015)\end{array}$ & $\begin{array}{c}0.054^{* * *} \\
(0.015)\end{array}$ & $\begin{array}{c}0.054^{* * *} \\
(0.021)\end{array}$ & $\begin{array}{c}0.065^{* * *} \\
(0.021)\end{array}$ & $\begin{array}{c}0.064^{* * *} \\
(0.021)\end{array}$ \\
\hline ReqEX & $\begin{array}{c}0.495^{* * *} \\
(0.011)\end{array}$ & $\begin{array}{c}0.133^{* * *} \\
(0.015)\end{array}$ & $\begin{array}{c}0.133^{* * *} \\
(0.025)\end{array}$ & $\begin{array}{c}0.059^{* *} \\
(0.026)\end{array}$ & $\begin{array}{l}0.060^{* *} \\
(0.026)\end{array}$ \\
\hline ReqIM & $\begin{array}{c}0.237^{* * *} \\
(0.011)\end{array}$ & $\begin{array}{c}0.044^{* * *} \\
(0.013)\end{array}$ & $\begin{array}{c}0.044^{* *} \\
(0.021)\end{array}$ & $\begin{array}{c}0.009 \\
(0.022)\end{array}$ & $\begin{array}{c}0.008 \\
(0.022)\end{array}$ \\
\hline $\ln ($ GDPEX) & & & & $\begin{array}{c}0.464^{* * *} \\
(0.033)\end{array}$ & $\begin{array}{c}0.463^{* * *} \\
(0.033)\end{array}$ \\
\hline $\ln (\mathrm{GDPIM})$ & & & & $\begin{array}{c}0.103 * * * \\
(0.030)\end{array}$ & $\begin{array}{c}0.100 * * * \\
(0.030)\end{array}$ \\
\hline Curruinon & & & & & $\begin{array}{c}0.323^{* * *} \\
(0.055)\end{array}$ \\
\hline RTA & & & & & $\begin{array}{c}0.115^{* * *} \\
(0.025)\end{array}$ \\
\hline Constant & $\begin{array}{c}0.349^{* * *} \\
(0.022)\end{array}$ & $\begin{array}{c}0.424^{* * *} \\
(0.016)\end{array}$ & $\begin{array}{c}0.424^{* * *} \\
(0.020)\end{array}$ & $\begin{array}{c}-4.341 * * * \\
(0.365)\end{array}$ & $\begin{array}{c}-4.310^{* * *} \\
(0.365)\end{array}$ \\
\hline Year FE & $\mathrm{Y}$ & $\mathrm{Y}$ & $\mathrm{Y}$ & $\mathrm{Y}$ & $\mathrm{Y}$ \\
\hline Country FE & $\mathrm{N}$ & Y & Y & Y & Y \\
\hline Observations & 335,445 & 335,445 & 335,445 & 309,555 & 308,253 \\
\hline R-squared & 0.004 & 0.006 & 0.006 & 0.009 & 0.009 \\
\hline $\begin{array}{c}\text { Number of } \\
\text { paired }\end{array}$ & 33,380 & 33,380 & 33,380 & 31,090 & 30,762 \\
\hline
\end{tabular}

Notes: Robustness standard errors are reported in parentheses; ${ }^{* * *} p<0.01, * * p<0.05$; all of the regressions are clustered at country pair level; country and year dummies are not reported here.

\subsection{Treatment-Effect Estimation Results}

All of the above reduced-form estimations assume that relatively better institutional quality is exogenous when the CIA is satisfied. If some variables are omitted, the above estimations could lead to biased estimators. However, previous studies have recognized that democracy fosters trade but that trade has no impact on (and does not even dampen) democracy [37]. Trade may potentially affect institutions, and the reverse correlation could lead to inconsistent estimators. To further confirm our estimation results, we apply the treatment effect model to uncover the casual effect through relatively better institutional quality by determining whether the institutional quality is higher or lower than the average (or median) world institutional quality. The logic is that the average (or median) institutional quality of all the countries is considered the exogenous variable for one country. If the country has relatively better institutional quality, it will have a higher probability of having relatively better institutional quality than its trade partners.

Table 5 reports the treatment effect results dealing with the potential endogenous issue. The first-stage result in Column (2) indicates the formulation of the instrument variable using a dummy variable indicating whether the country's institutional quality is relatively better than the median of all the countries' institutional quality or not. The results show that having relatively better institutional quality than the median of all the other countries' institutional quality is highly correlated with being relatively better than the trade partner. The gravity equation model estimation in the second stage is presented in Column (1) of Table 5. The two-stage estimation method makes the effect even larger than the benchmark regression. This may be due to measurement error issues resulting from the use of aggregate trade values calculated by applying the OLS method. Being better than the average of all other countries' institutional quality, instrumented as relatively better than its partner, is reported in 
Column (4). The causal effect of relatively better government institutional quality on exports is shown in the second stage (Column 3).

Table 5. Treatment effect estimations.

\begin{tabular}{|c|c|c|c|c|}
\hline & (1) & (2) & (3) & (4) \\
\hline Variables & $\begin{array}{l}\text { Treatment (2) } \\
\ln \text { (Exports) }\end{array}$ & First Stage & $\begin{array}{l}\text { Treatment (2) } \\
\ln \text { (Exports) }\end{array}$ & First Stage \\
\hline Relative & $\begin{array}{c}0.977^{* * * *} \\
(0.037)\end{array}$ & & $\begin{array}{c}1.056^{* * *} \\
(0.036)\end{array}$ & \\
\hline Better than median & & $\begin{array}{c}1.612^{* * *} \\
(0.008)\end{array}$ & & \\
\hline Better than average & & & & $\begin{array}{c}1.596^{* * *} \\
(0.008)\end{array}$ \\
\hline ReqEX & $\begin{array}{l}0.048 * \\
(0.028)\end{array}$ & & $\begin{array}{c}0.031 \\
(0.028)\end{array}$ & \\
\hline ReqIM & $\begin{array}{c}0.096^{* * *} \\
(0.023)\end{array}$ & & $\begin{array}{c}0.097^{* * *} \\
(0.023)\end{array}$ & \\
\hline $\ln (\mathrm{GDPEX})$ & $\begin{array}{c}-0.164^{* * * *} \\
(0.036)\end{array}$ & $\begin{array}{c}0.048^{* * *} \\
(0.002)\end{array}$ & $\begin{array}{c}-0.166^{* * *} \\
(0.036)\end{array}$ & $\begin{array}{c}0.050 * * * \\
(0.002)\end{array}$ \\
\hline $\ln (\mathrm{GDPIM})$ & $\begin{array}{c}0.251^{* * * *} \\
(0.033)\end{array}$ & $\begin{array}{c}-0.115^{* * *} \\
(0.002)\end{array}$ & $\begin{array}{c}0.254^{* * *} \\
(0.033)\end{array}$ & $\begin{array}{c}-0.114^{* * *} \\
(0.002)\end{array}$ \\
\hline $\ln ($ Distance $)$ & $\begin{array}{c}-1.066^{* * *} \\
(0.010)\end{array}$ & $\begin{array}{c}0.110 * * * \\
(0.005)\end{array}$ & $\begin{array}{c}-1.067^{* * *} \\
(0.010)\end{array}$ & $\begin{array}{c}0.103^{* * *} \\
(0.005)\end{array}$ \\
\hline Island & $\begin{array}{c}0.093 \\
(0.226)\end{array}$ & $\begin{array}{c}-0.182^{* * *} \\
(0.008)\end{array}$ & $\begin{array}{c}0.090 \\
(0.226)\end{array}$ & $\begin{array}{c}-0.178^{* * *} \\
(0.008)\end{array}$ \\
\hline Landl & $\begin{array}{l}0.395^{*} \\
(0.209)\end{array}$ & $\begin{array}{c}0.210 * * * \\
(0.006)\end{array}$ & $\begin{array}{l}0.390 * \\
(0.209)\end{array}$ & $\begin{array}{c}0.197^{* * * *} \\
(0.006)\end{array}$ \\
\hline Border & $\begin{array}{c}0.534^{* * *} \\
(0.045)\end{array}$ & $\begin{array}{c}0.143^{* * *} \\
(0.029)\end{array}$ & $\begin{array}{c}0.533^{* * *} \\
(0.046)\end{array}$ & $\begin{array}{c}0.144^{* * *} \\
(0.028)\end{array}$ \\
\hline Colony & $\begin{array}{c}1.030 * * * \\
(0.038)\end{array}$ & $\begin{array}{c}0.218^{* * *} \\
(0.045)\end{array}$ & $\begin{array}{c}1.032^{* * *} \\
(0.038)\end{array}$ & $\begin{array}{c}0.193^{* * *} \\
(0.045)\end{array}$ \\
\hline Comlang & $\begin{array}{c}0.245^{* * *} \\
(0.018)\end{array}$ & $\begin{array}{c}0.194^{* * * *} \\
(0.010)\end{array}$ & $\begin{array}{c}0.240^{* * *} \\
(0.018)\end{array}$ & $\begin{array}{c}0.204^{* * *} \\
(0.010)\end{array}$ \\
\hline Curruinon & $\begin{array}{c}-0.088^{* *} \\
(0.043)\end{array}$ & $\begin{array}{c}-0.392^{* * *} \\
(0.027)\end{array}$ & $\begin{array}{c}-0.072 * \\
(0.043)\end{array}$ & $\begin{array}{c}-0.422 * * * \\
(0.026)\end{array}$ \\
\hline RTA & $\begin{array}{c}0.462 * * * \\
(0.020)\end{array}$ & $\begin{array}{c}-0.227^{* * *} \\
(0.012)\end{array}$ & $\begin{array}{c}0.467^{* * *} \\
(0.020)\end{array}$ & $\begin{array}{c}-0.253^{* * *} \\
(0.012)\end{array}$ \\
\hline Year dummy & Y & & $\mathrm{Y}$ & \\
\hline Country dummy & $\mathrm{Y}$ & & Y & \\
\hline Observations & 184,631 & 184,631 & 184,631 & 184,631 \\
\hline
\end{tabular}

Notes: Robustness standard errors are reported in parentheses; ${ }^{* * *} p<0.01,{ }^{* *} p<0.05,{ }^{*} p<0.1$; all of the regressions are clustered at country pair level; country and year dummies are not reported here.

\section{Robustness Checks}

We take several steps to test the robustness of our empirical results. The robustness checks include zero trade issues, self-selection, multilateral trade assistance, and the endogeneity of GDP. For the statistical robustness tests, we use numerous techniques in relation to the modified gravity model.

\subsection{Do Zero Trade Values Matter?}

The above results were obtained using positive trade values. The reader may question what the relationship is between relatively better institutional quality and exports after considering the zero trade values, as zero trade values are common issues in international trade, as highlighted by Helpman et al. [38].

In relation to the robustness checks, first, we add a value of one to trade values as the dependent variable in Column (1) of Table 6. From the fixed effect model estimation, the effect of relatively better 
institutional quality on trade decreases to 0.054 . Second, as a robustness check, Column (2) presents the Tobit model estimation results, following the work of Eaton and Tamura on zero trade problems [39]. The effect of relatively better government institutions still has a statically significant effect on exports to its partners. Third, Silva and Tenreyro [40] point out that traditional OLS regression of a log-linearized gravity model leads to a biased estimator because of Jensen's inequality equation, $E(\ln y) \neq \log E(y)$ under heteroscedasticity. This implies that the expected value of the logarithm of a random variable is different from the logarithm of its expected value. To deal with this issue, we apply the Poisson maximum likelihood method in Column (3) of Table 6 to test the effect of relatively better institutional quality on exports. The effect size is driven down by dealing with the unobserved country and time fixed effects as the treatment-effect model regression estimator reported in Column (3) of Table 5. The fourth alternative approach is to use the pseudo Poisson maximum likelihood (PPML) estimator. This method can be used for trade, and it estimates the non-linear form of the gravity model and avoids dropping to zero trade. The estimation results are shown in Column (4). The effect of relatively better institutional quality holds, both economically and statistically. When the time fixed effects and country fixed effects are controlled for when applying the PPML, as reported in Column (4) of Table 6, all of the other conventional control variables—-such as GDP, geographic distance between trade partners, landlocked country dummy, island country dummy, common language, and the effect of a previous colonial relationship—show the expected significant effects with correct signs that are consistent with previous literature.

Table 6. Robustness checks I.

\begin{tabular}{|c|c|c|c|c|c|}
\hline & (1) & (2) & (3) & (4) & (5) \\
\hline Variables & $\begin{array}{c}\text { Fixed Effect } \\
\ln (\text { Exports }+1)\end{array}$ & $\begin{array}{c}\text { Tobit } \\
\ln (\text { Exports) }\end{array}$ & $\begin{array}{c}\text { Poisson } \\
\ln (\text { Exports }+1)\end{array}$ & $\begin{array}{c}\text { PPLM } \\
\ln (\text { Exports+1) }\end{array}$ & $\begin{array}{c}\text { HMR } \\
\ln \text { (Exports) }\end{array}$ \\
\hline Relative & $\begin{array}{l}0.054^{* * *} \\
(0.018)\end{array}$ & $\begin{array}{l}0.909 * * * \\
(0.052)\end{array}$ & $\begin{array}{c}0.077^{* * * *} \\
(0.006)\end{array}$ & $\begin{array}{l}0.068^{* * *} \\
(0.006)\end{array}$ & $\begin{array}{l}0.140^{* * *} \\
(0.165)\end{array}$ \\
\hline ReqEX & $\begin{array}{c}0.004 \\
(0.022)\end{array}$ & $\begin{array}{c}0.483^{* * *} \\
(0.078)\end{array}$ & $\begin{array}{c}-0.054^{* * * *} \\
(0.009)\end{array}$ & $\begin{array}{c}-0.050^{* * * *} \\
(0.010)\end{array}$ & $\begin{array}{l}0.051^{* *} \\
(0.025)\end{array}$ \\
\hline ReqIM & $\begin{array}{l}0.188^{* * * *} \\
(0.020)\end{array}$ & $\begin{array}{c}0.031 \\
(0.072)\end{array}$ & $\begin{array}{l}0.060^{* * *} \\
(0.007)\end{array}$ & $\begin{array}{l}0.103^{* * * *} \\
(0.002)\end{array}$ & $\begin{array}{l}0.032 * * \\
(0.008)\end{array}$ \\
\hline $\ln (\mathrm{GDPEX})$ & $\begin{array}{l}0.316^{* * *} \\
(0.039)\end{array}$ & $\begin{aligned}- & 0.781^{* * *} \\
& (0.107)\end{aligned}$ & $\begin{array}{c}0.349^{* * *} \\
(0.015)\end{array}$ & $\begin{array}{l}0.301^{* * * *} \\
(0.009)\end{array}$ & $\begin{array}{l}0.219^{* * *} \\
(0.022)\end{array}$ \\
\hline $\ln (\mathrm{GDPIM})$ & $\begin{array}{c}0.522^{* * *} \\
(0.032)\end{array}$ & $\begin{array}{l}-0.007 \\
(0.104)\end{array}$ & $\begin{array}{c}0.214^{* * *} \\
(0.012)\end{array}$ & $\begin{array}{c}0.230 * * * \\
(0.001)\end{array}$ & $\begin{array}{c}0.345^{* * *} \\
(0.005)\end{array}$ \\
\hline Curruinon & $\begin{array}{c}0.202 * * * \\
(0.049)\end{array}$ & $\begin{array}{c}-0.639 * * * \\
(0.148)\end{array}$ & $\begin{array}{c}0.090^{* * *} \\
(0.014)\end{array}$ & $\begin{array}{c}0.143 * * * \\
(0.013)\end{array}$ & $\begin{array}{c}-0.162^{* * *} \\
(0.048)\end{array}$ \\
\hline RTA & $\begin{array}{c}0.066 \\
(0.014)\end{array}$ & $\begin{array}{c}0.414^{* * *} \\
(0.063)\end{array}$ & $\begin{array}{l}0.041^{* * *} \\
(0.005)\end{array}$ & $\begin{array}{c}0.063^{* * *} \\
(0.005)\end{array}$ & $\begin{array}{c}-0.050^{* * *} \\
(0.019)\end{array}$ \\
\hline Year FE & $\mathrm{Y}$ & $\mathrm{Y}$ & $\mathrm{Y}$ & $\mathrm{Y}$ & $\mathrm{Y}$ \\
\hline Country FE & Y & $\mathrm{Y}$ & Y & Y & $\mathrm{Y}$ \\
\hline $\begin{array}{l}\text { R-squared/Pseudo } \\
\text { R2 }\end{array}$ & 0.43 & 0.08 & 0.38 & 0.73 & 0.618 \\
\hline Observations & 118,286 & 118,286 & 118,286 & 118,286 & 179,702 \\
\hline
\end{tabular}

Notes: Robustness standard errors are reported in parentheses; ${ }^{* * *} p<0.01,{ }^{* *} p<0.05$; all of the regressions are clustered at country pair level; country and year dummies are not reported here.

\subsection{Zero Trade and Heteroscedasticity}

Trade theory generally assumes that firms are identical, and these models can only explain zero trade flows as a measurement error, which misses some information or is the consequence of prohibitive trade costs. Building on the monopolistic competition model of heterogeneous firms developed by Helpman et al. [38], a model is specified in which consistent estimates of the value of trade can be obtained by following a two-stage procedure. 
In the first stage, a Tobit equation is applied to estimate the probability that two countries conduct international trade as a function of the observable variables in the gravity equation. In the second stage, the predicted components of this equation are used to control sample selection bias. In this paper, we use Helpman et al.'s [38] approach to estimate the gravity model with positive trade flows. Column (5) of Table 6 presents the results, showing that the effect is still statistically significant and positive.

\subsection{The Endogenous Variable of GDP}

It is well-known that trade is an important aspect of GDP. According to the assumption of OLS, even though we focus more on the variable of interest, the exogenous assumption of other control variables should also be satisfied. In order to deal with the endogenous issue of GDP, GDP per capita is used instead of GDP. The results are shown in Column (1) of Table 7. In addition, to deal with the endogenous issue of GDP, we use population as a proxy variable of GDP in the regressions, as reported in Columns (4) and (5) of Table 7. The effect of relatively better institutional quality on trade does not change hugely, and the effect is still positively significant.

Table 7. Robustness checks II.

\begin{tabular}{|c|c|c|c|c|c|}
\hline & (1) & (2) & (3) & (4) & (5) \\
\hline Variables & $\begin{array}{c}\text { FE } \\
\ln \text { (Exports) }\end{array}$ & $\begin{array}{c}\text { FE } \\
\ln (\text { Exports) }\end{array}$ & $\begin{array}{c}\text { FE } \\
\ln \text { (Exports) }\end{array}$ & $\begin{array}{c}\text { IV } \\
\ln \text { (Exports) }\end{array}$ & $\begin{array}{c}\text { IV } \\
\ln \text { (Exports) }\end{array}$ \\
\hline Relative & $\begin{array}{c}0.070^{* * *} \\
(0.022)\end{array}$ & $\begin{array}{c}0.020 \\
(0.027)\end{array}$ & $\begin{array}{c}0.076^{* *} \\
(0.030)\end{array}$ & $\begin{array}{c}0.045^{* *} \\
(0.022)\end{array}$ & $\begin{array}{c}0.046^{* *} \\
(0.022)\end{array}$ \\
\hline ReqEX & $\begin{array}{c}0.060 * * \\
(0.026)\end{array}$ & $\begin{array}{c}0.023 \\
(0.033)\end{array}$ & $\begin{array}{c}0.002 \\
(0.040)\end{array}$ & $\begin{array}{c}0.166^{* * *} \\
(0.026)\end{array}$ & $\begin{array}{c}0.152^{* * *} \\
(0.026)\end{array}$ \\
\hline ReqIM & $\begin{array}{c}0.009 \\
(0.022)\end{array}$ & $\begin{array}{c}0.026 \\
(0.029)\end{array}$ & $\begin{array}{l}-0.002 \\
(0.038)\end{array}$ & $\begin{array}{c}0.051 \text { ** } \\
(0.022)\end{array}$ & $\begin{array}{c}0.050 * * \\
(0.022)\end{array}$ \\
\hline $\ln (\mathrm{GDPpcEX})$ & $\begin{array}{c}0.465^{* * *} \\
(0.033)\end{array}$ & $\begin{array}{c}0.237^{* * *} \\
(0.066)\end{array}$ & $\begin{array}{c}0.344^{* * *} \\
(0.039)\end{array}$ & & \\
\hline $\ln (\mathrm{GDPpcIM})$ & $\begin{array}{c}0.098^{* * *} \\
(0.030)\end{array}$ & $\begin{array}{c}0.084 \\
(0.054)\end{array}$ & $\begin{array}{c}0.154^{* * *} \\
(0.040)\end{array}$ & & \\
\hline Curruinon & $\begin{array}{c}0.326^{* * *} \\
(0.057)\end{array}$ & $\begin{array}{c}0.264^{* * *} \\
(0.090)\end{array}$ & $\begin{array}{c}0.130 \\
(0.083)\end{array}$ & $\begin{array}{c}0.412 * * * \\
(0.059)\end{array}$ & $\begin{array}{c}0.410 * * * \\
(0.059)\end{array}$ \\
\hline RTA & $\begin{array}{c}0.124^{* * * *} \\
(0.026)\end{array}$ & $\begin{array}{c}0.209^{* * * *} \\
(0.040)\end{array}$ & $\begin{array}{l}-0.043 \\
(0.032)\end{array}$ & $\begin{array}{c}0.133^{* * * *} \\
(0.026)\end{array}$ & $\begin{array}{c}0.126^{* * *} \\
(0.026)\end{array}$ \\
\hline TRpriceEX & & & & & $\begin{array}{c}1.116^{* * *} \\
(0.083)\end{array}$ \\
\hline TRpriceEX & & & & & $\begin{array}{c}0.350 * * * \\
(0.065)\end{array}$ \\
\hline $\ln ($ POPEX) & & & & $\begin{array}{c}-0.525^{* * *} \\
(0.084)\end{array}$ & $\begin{array}{c}-0.554^{* * *} \\
(0.083)\end{array}$ \\
\hline $\ln (\mathrm{POPIM})$ & & & & $\begin{array}{c}0.602^{* * *} \\
(0.065)\end{array}$ & $\begin{array}{c}0.591^{* * *} \\
(0.065)\end{array}$ \\
\hline Observations & 255,581 & 76,649 & 165,891 & 259,710 & 259,710 \\
\hline
\end{tabular}

Notes: Robustness standard errors are reported in parentheses; ${ }^{* * *} p<0.01,{ }^{* *} p<0.05$; all of the regressions are clustered at country pair level; country and year dummies are not reported here.

\subsection{Different Time Periods}

The significance level not only depends on the effect size of the variable of interest but also on the variance of the error term. The variable is closely related to the sample size and sample periods. To test the robustness of significance, we divided the sample into two periods (i.e., before the year 2005 and after the year 2005). The effect of relatively better institutional quality on exports works after the year 2005, as shown in Column (3) of Table 7. This is potentially because those countries care more about their trade partners when trade uncertainty increases. 


\subsection{Multilateral Trade Resistance}

Unbiased estimates of the impact of distance and other bilateral variables on trade can be obtained by replacing the multilateral resistance indexes with importer and exporter dummies [36]. This has been confirmed in Column (1) of Table 6. These fixed effects capture all country-specific characteristics and control for a country's overall level of imports and exports. In an empirical analysis, Anderson and Marcouiller [24] used the Törnqvist index to approximate the multilateral resistance term. Following Anderson and Marcouiller's work [24], we added the import price index and export price index as a proxy for the multilateral resistance term. When adding the import and export price indexes, the effect of relatively better institutional quality on exports still holds, as reported in Column (5) of Table 7.

\subsection{Potential Outlier Issue}

The outliers of the variables may lead to potential bias regarding the effect size and significance level. In further robustness checks, we restrict the range of the dependent variable and other core control variables to run the regression using Equation (1). The robustness checks are reported in Table 8. In Column (1), we restrict the exporters' GDP in the range of 6-10 in the logarithmic value, and the effect size does change significantly. Following this, the importers' GDP in logarithmic value is within the range 6-10, and the estimation result is reported in Column (2). In terms of the export, the regression shows the estimation results in Column (3), where the export value in the logarithm is restricted between 3 and 12. Column (4) binds the distance value in the logarithm between 2 and 9. All the coefficients hold significance, and the effect sizes are between $5 \%$ and $6 \%$. The results are confirmed when dealing with the potential outlier issue.

Table 8. Robustness checks III.

\begin{tabular}{|c|c|c|c|c|}
\hline & (1) & (2) & (3) & (4) \\
\hline Variables & $\begin{array}{c}\text { Restrict Exporter's } \\
\text { GDP } \\
\text { Ln(Exports) }\end{array}$ & $\begin{array}{c}\text { Restrict Importer's } \\
\text { GDP } \\
\ln \text { (Exports) }\end{array}$ & $\begin{array}{c}\text { Restrict } \\
\ln \text { (Exports) } \\
\ln \text { (Exports) }\end{array}$ & $\begin{array}{c}\text { Restrict } \\
\ln \text { (Distance) } \\
\ln \text { (Exports) }\end{array}$ \\
\hline Relative & $\begin{array}{c}0.060^{* *} \\
(0.025)\end{array}$ & $\begin{array}{c}0.067^{* * *} \\
(0.024)\end{array}$ & $\begin{array}{l}0.049 * * \\
(0.020)\end{array}$ & $\begin{array}{l}0.064 * * \\
(0.027)\end{array}$ \\
\hline ReqEX & $\begin{array}{c}0.051 \\
(0.031)\end{array}$ & $\begin{array}{l}0.055^{* *} \\
(0.027)\end{array}$ & $\begin{array}{c}-0.086^{* * *} \\
(0.027)\end{array}$ & $\begin{array}{l}0.051 \text { * } \\
(0.031)\end{array}$ \\
\hline ReqIM & $\begin{array}{l}-0.011 \\
(0.028)\end{array}$ & $\begin{array}{l}-0.011 \\
(0.023)\end{array}$ & $\begin{array}{c}0.231^{* * *} \\
(0.024)\end{array}$ & $\begin{array}{l}0.044^{*} \\
(0.025)\end{array}$ \\
\hline $\ln (\mathrm{GDPpcEX})$ & $\begin{array}{c}0.406^{* * * *} \\
(0.046)\end{array}$ & $\begin{array}{c}0.468^{* * * *} \\
(0.035)\end{array}$ & $\begin{array}{l}-0.022 \\
(0.029)\end{array}$ & $\begin{array}{c}0.486^{* * *} \\
(0.041)\end{array}$ \\
\hline $\ln (\mathrm{GDPpcIM})$ & $\begin{array}{c}-0.017 \\
(0.040)\end{array}$ & $\begin{array}{l}0.082 * * \\
(0.033)\end{array}$ & $\begin{array}{c}0.270 * * * \\
(0.026)\end{array}$ & $\begin{array}{l}0.072 * \\
(0.040)\end{array}$ \\
\hline Curruinon & $\begin{array}{c}0.471^{* * *} \\
(0.154)\end{array}$ & $\begin{array}{c}0.439 * * * \\
(0.069)\end{array}$ & $\begin{array}{l}-0.057 \\
(0.036)\end{array}$ & $\begin{array}{c}0.018 \\
(0.248)\end{array}$ \\
\hline RTA & $\begin{array}{c}0.162^{* * *} \\
(0.043)\end{array}$ & $\begin{array}{c}0.141^{* * *} \\
(0.027)\end{array}$ & $\begin{array}{c}0.015 \\
(0.014)\end{array}$ & $\begin{array}{c}0.198^{* * *} \\
(0.036)\end{array}$ \\
\hline Observations & 173,266 & 173,266 & 173,266 & 173,266 \\
\hline
\end{tabular}

Notes: robustness standard errors are reported in parentheses; ${ }^{* * *} p<0.01,{ }^{* *} p<0.05,{ }^{*} p<0.1$; all of the regressions are clustered at country pair level; country and year dummies are not reported here.

\section{Concluding Remarks and Discussion}

\subsection{Main Conclusions}

It is frequently argued that democratic countries are more likely to trade with one another because they typically have better institutional quality. Thus, domestic institutional quality is considered an important driving force in terms of the selection of trade partners. However, few studies have focused on the effect of relatively better government institutional quality on trade. To address this 
gap, in this paper, we have shown the effect of a relative non-economic determinant-measured by a country's relatively better institutional quality than its partner-on exports. Relatively better institutional quality does matter for exports, dubbed the premium effect. Our findings provide a new potential channel through which institutional quality can promote exports. This is consistent with the findings of Nunn [27], where it was suggested that countries with poor institutions are net importers of contract-intensive products. The empirical findings are also in accordance with Costinot [41], who explores how reducing transaction costs can become a comparative advantage for trade. This paper provides strong evidence to prove that better institutions are complementary sources of comparative advantage. Ye et al. [42] proposed that institutional preferences can generate greater demand shocks with lower distress risk than those with higher distress risk. This results in countries with relatively better institutions outperforming those with lower quality institutions, as documented in this paper.

\subsection{Policy Implications}

Both economists and policymakers consider good institutions to be key factors that enhance the economic development of a country. The empirical findings of this paper highlight the role of institutional quality in international trade. In the context of rising anti-globalization sentiments, this paper provides a strong incentive for countries with better government institutional quality to trade with countries with lower institutional quality, which would result in increased sustainable world trade. The first important policy implication is that those countries with relatively better institutional quality should cooperate with countries with relatively lower institutional quality, thus contributing to the premium gains of the exporter and to sustainable trade. Second, the relatively lower institutional quality countries should seek out different channels to improve their institutional quality. Economic transition and permeant economic growth both open democratic windows of opportunity. Acemoglu and Robinson's [43] theory of political transition posits that transitory negative income shocks may increase the probability of improved democratic institutions. Permanent economic growth, as documented by Chisadza and Bittencourt [44], could also boost a country's democracy and the improvement of a government's institutional effectiveness. In addition, investment in education [45] is also an effective way of improving government institutional quality. A relatively lower institutional quality government could apply an economic booting policy and an education investment policy to improve its intuitional quality, thus assisting their exports and economic development.

\subsection{Limitations and Areas of Future Research}

Our study is not without limitations. The first limitation is that we did not analyze the effect of relative better institutional quality on different products. If product-level data were used in this topic, more specific policy implications could be drawn. Thus, we recommend that focusing on product-level research be an area of future research. Second, in this paper, we only identified the effects of relatively better government institutional quality on the intensive margins of trade. Researchers could analyze the effects of relatively better institutional quality on extensive margins of trade to compliment the findings of this study. Third, since this paper has presented some reasons as to why relatively better institutional quality effects exports and premium gains, testing the influencing mechanism in an empirical way would be an interesting avenue for future work. Fourth, in this paper, we measured government institutional quality using regular quality. It is well-known that democratic accountability, government effectiveness, political stability, regulatory quality, control of corruption, and the rule of law are effective indicators used to measure government institutional quality. It is worthwhile to test which indicator plays a more important role in terms of how it affects exports in future research.

Author Contributions: W.Y. and X.Y. initiated the idea and wrote the paper together. W.Y. contributed to the idea development and the revision of this paper. All authors have read and agreed to the published version of the manuscript.

Funding: Wenshou Yan acknowledges that the work is supported by National Natural Science Foundation of China (71903198). 
Acknowledgments: We are grateful to the editors and the anonymous referees for their invaluable comments that helped to improve this paper.

Conflicts of Interest: There is no conflict of interest identified for this research.

\section{Appendix A}

Table A1. Country list.

\begin{tabular}{|c|c|c|c|}
\hline Afghanistan & Djibouti & Lao PDR & Sao Tome and Principe \\
\hline Albania & Dominica & Latvia & Saudi Arabia \\
\hline Algeria & Dominican Republic & Lebanon & Senegal \\
\hline American Samoa & Ecuador & Lesotho & Serbia \\
\hline Angola & Egypt, Arab Rep. & Liberia & Seychelles \\
\hline Antigua and Barbuda & El Salvador & Libya & Sierra Leone \\
\hline Argentina & Equatorial Guinea & Lithuania & Singapore \\
\hline Armenia & Eritrea & Macao SAR, China & Slovak Republic \\
\hline Aruba & Estonia & Macedonia, FYR & Slovenia \\
\hline Australia & Ethiopia & Madagascar & Solomon Islands \\
\hline Austria & Fiji & Malawi & Somalia \\
\hline Azerbaijan & Finland & Malaysia & South Africa \\
\hline Bahamas, The & France & Maldives & Spain \\
\hline Bahrain & Gabon & Mali & Sri Lanka \\
\hline Bangladesh & Gambia, The & Malta & St. Kitts and Nevis \\
\hline Barbados & Georgia & Martinique & St. Lucia \\
\hline Belarus & Germany & Mauritania & $\begin{array}{l}\text { St. Vincent and the } \\
\text { Grenadines }\end{array}$ \\
\hline Belize & Ghana & Mauritius & Sudan \\
\hline Benin & Greece & Mexico & Suriname \\
\hline Bermuda & Greenland & Moldova & Swaziland \\
\hline Bhutan & Grenada & Mongolia & Sweden \\
\hline Bolivia & Guam & Morocco & Switzerland \\
\hline Bosnia and Herzegovina & Guatemala & Mozambique & Syrian Arab Republic \\
\hline Botswana & Guinea & Myanmar & Tajikistan \\
\hline Brazil & Guinea-Bissau & Namibia & Tanzania \\
\hline Brunei Darussalam & Guyana & Nepal & Thailand \\
\hline Bulgaria & Haiti & Netherlands & Timor-Leste \\
\hline Burkina Faso & Honduras & Netherlands Antilles & Togo \\
\hline Burundi & Hong Kong SAR, China & New Caledonia & Tonga \\
\hline Cabo Verde & Hungary & New Zealand & Trinidad and Tobago \\
\hline Cambodia & Iceland & Nicaragua & Tunisia \\
\hline Cameroon & India & Niger & Turkey \\
\hline Canada & Indonesia & Nigeria & Turkmenistan \\
\hline Central African Republic & Iran, Islamic Rep. & Norway & Tuvalu \\
\hline Chad & Iraq & Oman & Uganda \\
\hline Chile & Ireland & Pakistan & Ukraine \\
\hline China & Israel & Palau & United Arab Emirates \\
\hline Colombia & Italy & Panama & United Kingdom \\
\hline Comoros & Jamaica & Papua New Guinea & United States \\
\hline Congo, Dem. Rep. & Japan & Paraguay & Uruguay \\
\hline Congo, Rep. & Jordan & Peru & Uzbekistan \\
\hline Costa Rica & Kazakhstan & Philippines & Vanuatu \\
\hline Cote d'Ivoire & Kenya & Poland & Venezuela, RB \\
\hline Croatia & Kiribati & Portugal & Vietnam \\
\hline Cuba & Korea, Rep. & Qatar & West Bank and Gaza \\
\hline Cyprus & Kosovo & Russian Federation & Yemen, Rep. \\
\hline Czech Republic & Kuwait & Rwanda & Zambia \\
\hline Denmark & Kyrgyz Republic & Samoa & Zimbabwe \\
\hline
\end{tabular}




\section{References}

1. Araujo, L.; Mion, G.; Ornelas, E. Institutions and export dynamics. J. Int. Econ. 2016, 98, 2-20. [CrossRef]

2. Bliss, H.; Russett, B. Democratic trading partners: The liberal connection 1962-1989. J. Politics 1998, 60, 1126-1147. [CrossRef]

3. Acemoglu, D.; Johnson, S.; Robinson, J.A. Colonial origins of comparative development: An empirical investigation. Am. Econ. Rev. 2001, 91, 1369-1401. [CrossRef]

4. Acemoglu, D.; Johnson, S.; Robinson, J.A. Reversal of fortune: Geography and institutions in the making of the modern world income distribution. Q. J. Econ. 2002, 117, 1231-1294. [CrossRef]

5. Acemoglu, D.; Johnson, S.; Robinson, J.A. Institutions as a fundamental cause of long-run growth. In Handbook of Economic Growth; North Holland Publishing Co.: Amsterdam, The Netherlands, 2005; pp. 385-472.

6. Rodríguez-Pose, A.; Storper, M. Better rules or stronger communities? On the social foundations of institutional change and its economic effects. Econ. Geogr. 2006, 82, 1-25. [CrossRef]

7. Ali, M.A.; Rahman, M. The impact of institutional quality on the volume and organization of trade: Evidence from Malaysia. Int. J. Innov. Res. Man. 2014, 1, 21-30.

8. Yu, S.; Beugelsdijk, S.; de Haan, J. Trade, trust and the rule of law. Eur. J. Polit. Econ. 2015, 37, $102-115$. [CrossRef]

9. Nunn, N.; Trefler, D. Domestic institutions as a source of comparative advantage. In Handbook of International Economics; North Holland: Amsterdam, The Netherlands, 2014.

10. Álvarez, I.C.; Barbero, J.; Rodríguez-Pose, A.; Zofío, J. Does institutional quality matter for trade? Institutional conditions in a sectoral trade framework. World Dev. 2018, 103, 72-87. [CrossRef]

11. Wu, F.; Yan, X. Institutional quality and sustainable development of industries' exports: Evidence from China. Sustainability 2018, 10, 4173. [CrossRef]

12. Grofman, B.; Gray, M. Geopolitical Influences on Trade Openness in Thirty-One Long-Term Democracies, 1960-1995; University of California: Irvine, CA, USA, 2000.

13. Levchenko, A.A. Institutional quality and international trade. Rev. Econ. Stud. 2007, 74, 791-819. [CrossRef]

14. Levchenko, A.A. International trade and institutional change. J. Law. Econ. Organ. 2013, 29, $1145-1181$. [CrossRef]

15. Yu, M. Trade, democracy, and the gravity equation. J. Dev. Econ. 2010, 91, 289-300. [CrossRef]

16. Ju, J.; Wei, S.-J. When is quality of financial system a source of comparative advantage? J. Int. Econ. 2011, 84, 178-187. [CrossRef]

17. Ferguson, S.M.; Formai, S. Institution-driven comparative advantage, complex goods and organizational choice. J. Int. Econ. 2011, 90, 193-200. [CrossRef]

18. De Groot, H.L.F.; Linders, G.J.; Rietveld, P.; Subramanian, U. The Institutional Determinants of Bilateral Trade Patterns. Kyklos 2004, 57, 103-123. [CrossRef]

19. Pierre, G.M.; Sekkat, K. Institutional quality and trade: Which institutions? Which trade. Econ. Inq. 2008, 46, 227-240.

20. Kim, I.S.; Londregan, J.; Ratkovic, M. Politics, Institutions, and Trade; Working Paper; Princeton University: Princeton, NJ, USA, 2016; Available online: https://wws.princeton.edu/faculty-research/research/item/politicsinstitutions-and-trade (accessed on 11 October 2019).

21. Anderson, J.E.; Young, L. Trade implies law: The power of the weak. Natl. Bur. Econ. Res. 2000. [CrossRef]

22. Soeng, R.; Cuyvers, L. Domestic institutions and export performance: Evidence for Cambodia. J. Int. Trade. Econ. Dev. 2018, 27, 389-408. [CrossRef]

23. Beverelli, C.; Fiorini, M.; Hoekman, B. Services trade policy and manufacturing productivity: The role of institutions. J. Int. Econ. 2017, 104, 166-182. [CrossRef]

24. Anderson, J.E.; Marcouiller, D. Insecurity and the Pattern of Trade: An Empirical Investigation. Rev. Econ. Stat. 2002, 84, 342-352. [CrossRef]

25. Francois, J.; Manchin, M. Institutions, Infrastructure, and Trade. World Dev. 2013, 46, 165-175. [CrossRef]

26. Soderlund, B.; Tingvall, P.G. Dynamic effects of institutions on firm-level exports. Rev. World. Econ. 2014, 150, 277-308. [CrossRef]

27. Nunn, N. Relationship-Specificity, Incomplete Contracts, and the Pattern of Trade. Q. J. Econ. 2007, 122, 569-600. [CrossRef]

28. Baldwin, R.; Taglioni, D. Gravity for dummies and dummies for gravity equations. NBER 2006. [CrossRef] 
29. Anderson, J.E.; Wincoop, E.V. Gravity with Gravitas: A Solution to the Border Puzzle. Am. Econ. Rev. 2003, 93, 170-192. [CrossRef]

30. Feenstra, R.C. Advanced International Trade: Theory and Evidence, 2nd ed.; Princeton University Press: Princeton, NJ, USA, 2016.

31. Angrist, J.D.; Pischke, J.S. Mostly Harmless Econometrics: An Empiricist's Companion; Princeton University Press: Princeton, NJ, USA, 2009.

32. Heckman, J. Sample selection bias as a specification error. Econometrica 1979, 47, 153-161. [CrossRef]

33. Glick, R.; Rose, A.K. Currency unions and trade: A post-EMU reassessment. Eur. Econ. Rev. 2016, 87, 78-91. [CrossRef]

34. Rose, A.K. Soft power and exports. Rev. Int. Econ. 2019, 27, 1573-1590. [CrossRef]

35. Kaufmann, D. Worldwide Governance Indicators. 2019. Available online: http://info.worldbank.org/ governance/wgi/Home/downLoadFile?fileName=wgidataset_stata.zip (accessed on 12 October 2019).

36. Anderson, J.E.; Wincoop, E.V. Trade cost. J. Econ. Lit. 2004, 42, 691-751. [CrossRef]

37. Eichengreen, B.; Leblang, D. Democracy and globalization. Econ. Pol. 2008, 20, 289-334. [CrossRef]

38. Helpman, E.; Melitz, M.; Rubinstein, Y. Estimating trade flows: Trading partners and trading volumes. Q. J. Econ. 2008, 123, 441-487. [CrossRef]

39. Eaton, J.; Tamura, A. Bilateralism and Regionalism in Japanese and U.S. Trade and Direct Foreign Investment Patterns. J. Jpn. Int. Econ. 1994, 8, 478-510. [CrossRef]

40. Silva, J.M.C.S.; Tenreyro, S. The log of gravity. Rev. Econ. Stat. 2006, 88, 641-658. [CrossRef]

41. Costinot, A. On the origins of comparative advantage. J. Int. Econ. 2009, 77, 255-264. [CrossRef]

42. Ye, Q.; Wu, Y.; Liu, J. Institutional preferences, demand shocks and the distress anomaly. Br. Account. Rev. 2019, 51, 72-91. [CrossRef]

43. Acemoglu, D.; Robinson, J.A. Economic Origins of Dictatorship and Democracy; Cambridge University Press: New York, NY, USA, 2006.

44. Chisadza, C.; Bittencourt, M. Economic development and democracy: The modernization hypothesis in sub-Saharan Africa. Soc. Sci. J. 2019, 56, 243-254. [CrossRef]

45. Apergis, N. Education and democracy: New evidence from 161 countries. Econ. Model. 2018, 71, 59-67. [CrossRef] 